\title{
AFTER THE BRITISH WORLD
}

DR RACHEL BRIGHT \& DR ANDREW DILLEY

KEELE UNIVERSITY \& UNIVERSITY OF ABERDEEN

Running Head: After the British World

\section{Abstract [186 words]}

Within the expanding field of global history, historians often conceive of distinct integrated 'worlds': discrete if permeable cultural units capable of coherent study. Some are defined exogenously through factors such as oceanic geography, others are conceived of endogenously through the cultures and identities of their adherents. In this context this article critically assesses the recent voluminous literature on the British world: a unit increasingly distinguished from British imperial history and defined by the networks and identities of global Britishness. The article argues that the British world, while making valuable contributions to the historiography of empire and of individual nations, fails ultimately to achieve sufficiently clear definition to constitute a distinctive field of study and neglects the crucial concerns of imperial history with politics and power, while flattening time, space and neglecting diversity. While highlighting many key concerns, other methodologies such as settler colonialism, whiteness studies, or revivified imperial history are better placed to take these on than the nebulous concept of a world. More broadly, an analysis of the British world highlights the problems inherent in attempting to define a field endogenously through a focus an identity.

Word Count ex bib inc. footnotes: 10,485. 
Over the last twenty years, historians have sought to transcend the long established reification of the nation-state as the basic unit of historical analysis. A world increasingly conscious of its own interconnectedness demanded, or seemed to demand, new forms of history. Global history, transnational history, revivified world history, and imperial history all rose to the challenge while national histories were set in transnational contexts. ${ }^{1}$ New units of analysis attracted increasing attention and by a strange linguistic quirk the globe became partitioned into a series of 'worlds', described by Bernard Baylyn as 'vast cultural area[s] distinctive in world history. ${ }^{2}$ Baylyn wrote about the Atlantic world, and maritime worlds in particular have blossomed as historians have charted exchanges of ideas, goods, and peoples in the Atlantic, Indian and Pacific oceans. ${ }^{3}$ For many historians, oceans and seas have provided a consistent (if not uncontested) framework within which to trace transnational processes across the boundaries of states and empires. ${ }^{4}$ Shared cultures and identities have also formed the basis of 'worlds' history, such as the trading networks of the Dar-al-Islam. ${ }^{5}$ The Atlantic itself has been subdivided in this way, to produce British, French, Lusophone, Spanish, even Canadian Atlantics, along with a Green, a Red, and a Black Atlantic. ${ }^{6}$ The conceptual differences between the maritime worlds and such culturally defined approaches are significant. The maritime approach defines a cultural 'world' exogenously through the operation of communications systems shaped by the interaction of the sea and maritime technology at their core. Where culture and identity themselves provide the building blocks for the world, the field is conceived endogenously through the forms of identity adopted by, and the connections forged between, historical actors.

This article critically assesses this latter approach: the attempt to construct a world as a field of study using cultural connections and identities, rather than a set geographical 
space. What are the merits and perils of such an approach? We take as our case study the increasingly voluminous literature about the so-called 'British world' of the nineteenth and twentieth centuries, in order to better understand and critique this broader 'worlds' approach to global history. ${ }^{7}$ This literature has multiple points of origin but grew from a coalescence of historians of the British empire seeking to restore the British colonies of settlement to a prominent place in the study of empire, with national historians of those former colonies seeking to restore consideration of the imperial connection. Yet, as with other forms of 'worlds' history, many studying the British world have sought to distinguish the approach from these imperial or national histories. This literature then provides a perfect prism to assess the recent global turn in scholarship and particularly of forms of 'worlds' history which place identity front and centre.

To this end, we undertake a critical assessment of the achievements and shortcomings of the British world, as a case study of the opportunities and pitfalls of the more general global turn in scholarship. With respect to the contribution of the British world itself, we argue that much of value has emerged, especially in the way the conferences and writings have brought together disparate scholars from across the globe. This has effected several necessary transformations within the study of the British empire, particularly the reemphasising of the importance of migration and the settler empire after several generations of relative neglect. Equally it has contributed to the reintegration of imperial dimensions into the national historiographies of Australia, Canada, and New Zealand, and to a lesser extent South Africa and the United Kingdom.

Nonetheless, the British world has been less successful when offered as a fundamental departure from older imperial and national histories. We argue that, in the 
final analysis, the British world is best understood as a movement within rather than beyond the history of British imperialism, and that many authors in practice have acknowledged this. However we suggest that by seemingly rejecting the historiographical framework of empire, the British world omits or only implicitly acknowledges important analytical dimensions, particularly ones bound up with power and politics. Moreover, the conceptual core of the British world, combining an attention to cultural networks combined with a focus on British identity, is not sufficient to delineate a distinct field of study. Indeed, using something as subjective as 'British' as an analytical framework can obscure what it seeks to analyse more than it can enlighten. An expanded conception of empire and imperial history serves better than attempting to conceptualise a separate world. This in turn helps to illuminate for scholars of global history some of the strengths and weaknesses of using 'worlds' defined by culture and identity as analytical frameworks.

The British world originated from a series of conferences held in London (1998), Cape Town (2002), Calgary (2003), and Bristol (2007). The original organisers combined historians of the British empire and Commonwealth, and of the 'old dominions' (a term we shall return to later), establishing a core combination which has subsequently characterised British world scholars and scholarship. ${ }^{8}$ The initial conferences were motivated by dissatisfaction with existing historiographical boundaries. On the one hand, they represented a growing sense that settlement empire and the 'old dominions' had become marginalised in the historiographies of empire. ${ }^{9}$ Historians studying the post-1776 British empire in the second 
half of the twentieth century had tended to focus more on the 'dependent' empire in Africa and Asia in dialogue with area studies specialists. ${ }^{10}$ As post-colonial studies flourished following Said's seminal study of orientalism, developing into the new 'imperial history', scholarly attention was again drawn to empires of difference in Africa, Asia, and the Caribbean. ${ }^{11}$ On the other hand, a certain insularity developed in the writing of Canadian, Australian, New Zealand, and (with strong caveats) South African national historiographies. ${ }^{12}$ Notwithstanding comparative work exploring dependency theory, ${ }^{13}$ the creation of national (if not explicitly nationalist) literatures tended to focus increasingly on internal developments at the expense of external connections. Hence a key motivation behind the British world was to restore the 'lodestone of empire' to the study of national histories of the dominions. ${ }^{14}$

These historiographical complaints were explicit in the introductions to the edited collections which emerged from the first two conferences. Carl Bridge and Kent Fedorowich, and Phillip Buckner and R. Douglas Francis criticised both the concerns and conceptual tools of post-1950s British imperial history: the concern with informal and formal power, the simplistic spatial division of core and periphery, the relative neglect of the dominions, as well as the supposedly exclusive post-colonial concern with encounters with the 'other'. ${ }^{15}$ They also criticised the insularity of national historiographies of the old dominions for neglecting comparisons and the historical significance of the British connection and Britishness. Instead, they argued it was necessary to 'rediscover' what they termed the British world.

The precise genesis of the term is nebulous. Both collections emphasised that the 'British world' was used throughout the late nineteenth and early twentieth centuries to 
describe Britain and the settler colonies. It should, however, be noted: 'Greater Britain', 'empire', or (from World War I) 'British Commonwealth' tripped more easily off contemporary tongues, and from the pens of authors such as J. R. Seeley, J. A. Froude, Charles Dilke or Richard Jebb who are frequently cited in British world publications. ${ }^{16}$ The term more closely derived from J. G. A. Pocock's reflections on the 'new British History', which he conceived as stretching beyond the confines of the Atlantic archipelago: 'There was a British world, both European and oceanic, in the nineteenth and twentieth centuries: it had a history. ${ }^{17}$ Thus James Belich cited Pocock when asserting there existed a "transnational cultural entity based upon a populist form of pan-Britonism". ${ }^{18}$ The implications of these early debts to late-nineteenth century imperial federalism and to new British History - especially Pocock - are discussed later.

The British world then, emerged as a corrective within imperial and national historiographies, but claimed to be distinctive. Bridge and Fedorowich's initial 2003 characterisation of the British world established the basic conceptual framework, and is worth extensive summary. It was, they write, 'a phenomenon of mass migration from the British Isles. Its core was the "neo-Britains" where migrants found they could transfer into societies with familiar cultural values'. Based on improving 'trans-oceanic and transcontinental travel and communications' this world became more 'intricately inter-connected and self-defining'. The identity at the core of the world, Britishness, meant 'exercising full civil rights within a liberal, pluralistic polity 'or aspiring to this status. Although "'whiteness" was a dominant element... this world was not exclusively white' as people from differing ethnic backgrounds 'adopted British identity' and were 'accepted to varying degrees as part of the British world, within the white Dominions, elsewhere in the empire and to some 
extent outside it'. Crucially, the 'cultural glue which held together this British world consisted not only of sentiment and shared institutional values but also of a plethora of networks'. Thus, and here came the distinction from imperial history, the British world was not a top down political structure but rather a form of 'globalisation from below', built largely through migration and ideas of British identity. ${ }^{19}$

However, the British world, as introduced by Bridge and Fedorowich, possessed several ambiguities. While that world was judged to be the product of the interaction of diaspora, culture, and identity, the meanings and implications of these concepts were not explored. ${ }^{20}$ The core identity defining the field of study (the 'world'), Britishness, could be seen as the product of migration from Britain (an ethnic diaspora), or it could be a civic identity, a set of ideas and values not - in principle - tied to migration or ethnicity. Authors have often slipped between both treatments, while the spatial and temporal definitions of the British world remained equally unclear. As Phillip Buckner and R. Francis, two of the founders of the approach, observed, 'even the founders of the British world project were never uniform in their interpretation of what should be included within the framework of the project'. ${ }^{21}$ At the outset, the British world possessed a conceptual ambiguity with authors slipping between differing conceptions.

This became particularly problematic because the British world was linked with two further bodies of literature, both with their own ambiguous relationships to the historiography of empire (and indeed with national historiographies). First, following J. G. A. Pocock, the British world developed connections to the project of new British history and the study of Britishness. Thus Linda Colley's work on British identify became a clear inspiration, although British world literature has tended to omit the processes of forging of a 
composite identity through the identification of external others at the core of Colley's work. $^{22}$ Second, by placing social networks at the heart of analysis, the British world became associated with a growing literature on Victorian-era 'imperial networks', particularly strengthening the British world's concern to break down the binary opposition between British metropole and colonial 'peripheries' to consider cross-colonial connections. ${ }^{23}$ Curiously, fewer parallels were made with the burgeoning literature on the Atlantic world (especially David Armitage's revival of the term 'Greater Britain'). ${ }^{24}$ In part this reflects the differing periods that pre-occupy the Atlantic world (the seventeenth and eighteenth centuries) and the British world (late-nineteenth and twentieth centuries), as well as a more general tendency for 'worlds' studies to concentrate on the periods where interconnections appear strongest.

From these different currents, a variegated British world literature has emerged, generally in edited collections based on the conferences. All follow a pattern, juxtaposing studies of Britain, the 'old dominions' and, occasionally, other locations within and beyond the British empire (constitutionally defined). The collections give a de facto definition of the British world which places the settlement empire at the core. ${ }^{25}$ These publications have been characterised by a profound slipperiness in terminology. As Phillip Buckner and Carl Bridge noted about one conference, there was 'a certain imprecision in the meaning of terms such as Britishness, imperialism, empire loyalty, British race patriotism, colonial nationalism and Greater Britain'. They, like most writers of the British world, have argued that this imprecision is a strength and not a weakness of the concept. Networks and identities are, 'by their very nature... contested and fluid', as are 'the parameters of the British world'. ${ }^{26}$ The 2005 book from the Calgary conference has chapters which use 'British 
world', 'Anglo-world', 'imperial networks', 'white settler colonies', 'Britishness', 'Englishspeaking worlds', and 'settler societies' without really attempting, as the editors note, to define or differentiate. ${ }^{27}$ Most frequently, the term British world is used as a synonym for Britain and the settler colonies, but only implicitly and at times authors also stretch it to include the US or other concentrations of expatriates (Shanghai has become a cause celebre). ${ }^{28}$ Although perhaps it is unfair to expect coherence to emerge in collections based on conferences, nonetheless the heterogeneous vocabulary often used highlights a problem: many different and distinct phenomena are all collapsed together without precision.

These problems of lexicon reflect a broader problem within existing imperial historiography about settler colonies. 'Dominions' is frequently (and confusingly) used by scholars as a synonym for 'settler colony' with little acknowledgement that 'dominion' was not used to denote a separate constitutional status until $1907 .{ }^{29}$ Historians repeatedly rob the term of its constitutional specificity. The term has also on occasion been stretched to incorporate 'honorary dominions' to describe Shanghai, Argentina, Uruguay and Chile. ${ }^{30}$ The fluidity of 'British' has also become evident in recent years. Many Australian and New Zealand scholars have instead adopted 'Anglo-Celtic', which is problematic for several reasons, mainly because of the prioritisation of English ('Anglo') and the fact that the original Celts were not a cultural or ethnic grouping at all but a loose trading network, so the term depends on pseudo-history for significance. The point is that much British world writing tends to be desperately unclear about where is included, and how these places are defined as a network. The British world lacks definition. 
Perhaps the greatest problem lies in the British world's treatment of the US. Given the British world's emphasis on diasporic networks and identities (on 'globalisation from below'), and the overwhelming popularity of the US as a destination for British migrants, the US seems logically to be part of the British world. Indeed if one conceptualised through networks and identities, it rivals Britain as a core. Yet in practice the British world literature generally holds the US at arms-length in an ambiguous half-way house without successfully explaining why (the implicit answer is clear enough: it was not a part of the British imperium, but of a 'white' or English-speaking network). Very few contributions to the edited collections give the US much attention.

The ambiguities of the British world approach are more fully exposed in the two major monographs to have grown out of the literature. ${ }^{31}$ These attempt to distinguish the British world from the British empire and integrate the analysis of economics, culture, and migratory networks to contribute to the history of nineteenth century globalisation. First, Gary Magee and Andrew Thompson's Empire and Globalisation provides much needed theoretical ballast to the British world, and also seeks to connect the literature to the history of globalisation in the nineteenth century. Their discussion brings to bear the full force of network theory to elaborate on Bridge and Fedorowich's brief account of the British world. They argue that due to the operation of 'co-ethnic networks' and the bonds of trust facilitated by a shared British culture, the British world was a tightly integrated economic unit within the late nineteenth century global economy as demonstrated by patterns of migration, investment and trade. ${ }^{32}$ Magee and Thompson's adoption of network theory and emphasis on culture as the defining feature of the British world's 'cultural economy' leads them to adopt an ambiguous spatial framework, generally placing Britain and the settler 
colonies at the core of their analysis, but also including other clusters of expatriates, even at times the United States. Indeed, the occasional inclusion of the US is central to Magee and Thompson's core claim that the 'first phase' of 'modern globalisation' was 'nurtured within the confines of the British world'. ${ }^{33}$

Nonetheless, they frequently use the terms British world, empire, and imperial as synonymous, and tend to frame their argument through the interrelationship of Britain and the settler colonies, while describing the US as having an 'ambiguous' relationship with the British world. $^{34}$ It is true that the tryptic of late nineteenth century writers so frequently cited (Dilke, Froude, and Seeley) were divided as to how to treat Americans: Charles Dilke even altered his position, first including and then excluding the US. ${ }^{35}$ Nonetheless, contemporaries were divided rather than ambiguous on the dimensions of 'Greater Britain' (or rather whether those dimensions were contiguous with the English-speaking world or confined to the British Empire). ${ }^{36}$ No contemporary imagined the US to be subject to the rhetoric or institutional practices of the British imperium, hence the evolution of an alternate language about the English-speaking world or Anglo-Saxon world. ${ }^{37}$ No approach to economic globalisation in the nineteenth century can treat the US (the major emerging component of the Atlantic trading system and the largest single destination for European migrants, European capital, and trade) so ambiguously. ${ }^{38}$ Thus the British world, in and of itself, does not prove sufficient for the conceptual work required of it by Magee and Thompson's otherwise admirable and ambitious analysis.

James Belich's Replenishing the Earth also seeks to offer an account of the central contribution of anglophone settlers to the evolution of the world economy in the long nineteenth century. Belich, unlike Magee and Thomson, gives full and equal treatment to 
the United States. Yet for our purposes, the conceptual construct he adopts is important. Belich redraws the map of the world to describe what he calls a two-fold 'Anglo-world' - a term adopted to denote Britain, the old dominions (but only partially including South Africa), and the United States. Geography is re-imagined. The east coast of the US is separated from the west and reclassified as an 'oldland' (a long settled core), while the dominions of the British empire are grouped together as 'Greater Britain' or the 'British West; (not the British world), joining the American west as 'newlands'. Belich then describes how cycles of boom and bust drive the colonisation of the new by the old and the social, economic, and cultural relations between them. ${ }^{39}$ Subdividing the Anglo-world into symmetrical, analogous, units avoids the problems incurred by Magee and Thompson: the US is not an ambiguity. The move also helpfully exposes the economic relations at play. Yet Belich's account too contains an occlusion. He explicitly sets out not to write the political history of the Anglo-world, yet the subdivisions on which the analysis is built are political. After all, the $49^{\text {th }}$ parallel has absolutely no geographical or economic significance. Politics, not economics, determines the inclusion of the Canadian west in Greater Britain not the American west. This failure to grapple with many of the political institutions underpinning such a focus remains a problem rife in British world literature.

The British world then has generated a growing and variegated literature, including several monographs. Much of this work has made useful diverse contributions, especially in re-connecting the national historiographies of Britain and the colonies of settlement with that of the British empire. ${ }^{40}$ Yet when applied to major monographs, the British world concept becomes problematic. Magee and Thompson took the emphasis on socio-cultural networks to its logical conclusion - largely including the US - yet in so doing treated the US 
as an ambiguous exception. Belich conversely overcame similar ambiguities by implicitly reintroducing the political.

In their different ways, both monographs place under close scrutiny the twin concepts around which the British world is built: 'world', and 'Britishness'. In response, several scholars have attempted to address such criticisms by imparting greater coherence to these key concepts. Tamson Pietsch has interrogated the concept of the 'world', Saul Dubow the idea of Britishness. Their attempts to rescue the British world framework bear closer scrutiny.

Pietsch subjects the frequent anxieties about the spatial dimensions of the British world to serious critique. She argues that it is not, in fact, helpful to consider the British world as a fixed space. She draws in particular on cultural geographers' theorisation of 'space not as a fixed entity that we move through but rather as something that gets made by people and their contexts'. Thus, she argues that:

historians of Britain and its empire need to think not of a singular British World but rather of multiple, produced British world spaces: we need to think not only about the places in which people lived but also about the networks and exchanges that shaped their lives and the emotions and feelings that created internal landscapes of longing and belonging. ${ }^{41}$

Pietsch draws specifically on David Harvey's distinction between three kinds of space: absolute ('bounded and immovable'), relative ('transportation relations and of commodity and monetary circulation'), and relational ('space that lives inside us-the space produced 
by our experiences, memories, fears, and dreams). ${ }^{42}$ As a result, Pietsch argues that the British world concept is best approached with the recognition that all three conceptions of space are at work, although most attention is given to relational space in her article. Hence she rebrands this as 'British worlds' to provide 'a way of talking about the multiple and intersecting yet necessarily limited worlds that long-distance connections created' within which a multiplicity of ideas of Britain and Britishness operated. ${ }^{43}$ She illustrates her argument through an analysis of the multiple discourses of space at work in a single event, the 1903 Allied Colonial Universities Conference, where different attendees envisioned all possible meanings of the British world. Thus she suggests that the imprecision inherent in the term 'worlds' is perhaps its attraction. In her imagining of the British worlds, it is impossible, and becomes no longer necessary, to finally decide whether the United States, Anglo-phone expatriates in Buenos Aires, or the redoubtable 'Shanghailanders' are in or out.

There are, however, limitations to this line of argument. In her article, Pietsch can deconstruct conceptions of space in part precisely because she chooses a case study which, notwithstanding the multiple discourses in operation, is framed by a relatively unambiguous and explicitly constitutionally imperial conception of empire ('Allied Colonial Conference'). Inevitably there are multiple discourses of Britishness extant globally, but her example suggests that such a use of space could easily fit within existing histories of the British empire; it is not clear why a separate analytical framework of British worlds is actually necessary. What would be the value of studying 'British worlds', as opposed to different identities or networks within the empire or some other existing framework? Indeed, this highlights the need not only to specify and delineate the different imagined communities, the different discourses, operating within the British world(s) but also to consider the 
absolute and relative spatial forces which might lend some coherence to these imaginings. As Ben Anderson has emphasised, the meaning and materiality of space cannot be divided into neat separate categories. ${ }^{44}$ Therefore, the pluralisation of the term, inviting a consideration of British worlds, in and of itself cannot not salvage the concept.

Britishness, of course, has also provided a de facto reference point to distinguish the history of the British world from the history of the British empire. Such a close examination of the meaning of Britishness lies at the heart of Saul Dubow's widely read re-thinking of the British world from the perspective of South Africa, which is treated ambiguously by most British world literature. Dubow argues that the British world should help tease out a Britishness which could not simply be defined by 'ethnic' or 'racial' considerations. Instead, Britishness was 'a composite, rather than an exclusive, form of identity'. ${ }^{45}$ Dubow's version of the British world is an imagined community, distinguished from the British empire, with 'British' used in an 'adjectival' not a 'possessive' sense. It was imagined differently by different people at different times for different reasons and only one identity which overlapped with many others in South Africa. Drawing on work by Donal Lowry in particular, he emphasised the role of 'non-British' outsiders who could still "'feel as profound a sense of loyalty to the Crown and Empire as did their Anglo-Protestant compatriots."'. ${ }^{46}$ The British world in South Africa was not the study of the migration of Britons abroad and their links with Britishness, but a far more inclusive 'set of affinities' which people felt towards Britain and Britishness for a variety of reasons. ${ }^{47}$ Dubow's contribution differentiates the British world more sharply from the British empire, and implies an interesting avenue of enquiry to which we shall return: a global history of Britishness. Yet having made the conceptual distinction, he (like so many writers on the British world) called into question the 
significance of the distinction by using the terms the 'British Empire' and 'British world' almost interchangeably as he developed a case study of South African usages of Britishness.

A striking comparison is Andrew Thompson's exploration of similar ideas about identity in South Africa using the concept of 'loyalism', rather than the British world. He adapted a term coined by British imperial authorities in the late nineteenth century to differentiate white, English-speaking settlers who supported British imperial rule from the rest of the population. In Thompson's article, 'loyalism' was defined more broadly as people being loyal to 'an idea of "Britain"'. He also identified three key factors 'which shaped South African loyalism - geography, ideology and ethnicity', similar to the ideas expressed about Britishness within British world literature. ${ }^{48}$ Both Dubow and Thompson rightly made clear that it is important to not constantly divide colonists and colonised into separate groups, that their identities were complex, contested and often overlapped. Thompson and Dubow discuss similar things, but one uses the concept of the British world and the other loyalism, and it is not clear that either offer a distinct advantage over the other except that loyalism is grounded more directly in contemporary language.

\section{II}

In practice, the British world has grown out of British imperial history and has been used to re-emphasise the importance of the settlement empire, self-governing and forged by migration, rather than the dependent empire. The reflective accounts of Pietsch, Dubow, or indeed Magee and Thompson, seek to complicate and challenge crude spatial divisions (core-periphery) and associated assumptions about (always unequal) power which supposedly characterised an older imperial literature. A re-emphasis on British-dominion 
relations, highlighting the history of migration and the like, has undoubtedly been valuable. However a distinctive concept of the British world is not really needed to achieve this. Indeed, in practice, it has often added yet another layer of jargon to the already unclear terminology used to describe Britain and the colonies of settlement. Equally, a global and transnational turn has made valuable contributions to the historiographies of individual locations as has the stimulus for comparative studies. But it is not clear that the British world is necessary to 'go global'. Dubow's and Pietsch's efforts to inject greater nuance and clarity into the term reveal its inextricable limitations. There is no reason not to use a term like the British world to enrich a pre-existing field, but this does not in and of itself create a separate analytical field.

It is true that, in 2003, there was a need for historians of empire to reconsider the colonies of settlement which had, hitherto, become marginalised. Their distinctive internal dynamics - the colonialism of settler colonies - certainly needed to be analysed beyond individual national contexts. The British world literature may have helped here. Belich's study of the 'Anglo-World' might be considered a stimulating argument as to how and why anglophone settle colonialism was distinctive due to unique global connections. ${ }^{49}$ However the study of 'settle colonialism' itself has increasingly developed as an independent field of study since Patrick Wolfe's 1998 book, Settle colonialism and the transformation of anthropology. While economic works on development theory continue to loosely use the term, ${ }^{50}$ this has increasingly given way to a specific field of analysis, defined by permanent settlement, land ownership, and 'native' annihilation. The theoretical underpinnings, especially relating to its distinctiveness from imperial and colonial history, have been developed in two books, as well as in a journal founded in 2011 by Edward Cavanagh and 
Lorenzo Veracini. ${ }^{51}$ Some of this burgeoning literature does the work that the British world has tried to do, by focusing on how settlers developed their own cultures and identities and how indigenous groups fit in this (as well as how such definitions such as 'settler' and 'indigenous' were constructed). Perhaps most importantly, it embeds explicit considerations of power, lacking in most British world scholarship. ${ }^{52}$ Furthermore, much of the literature emphasises that settle colonialism can only be understood in a global context, by exploring comparisons as well as connections. ${ }^{53}$ Thus the literature on settle colonialism now widens the lens to examine locations within (Australia, New Zealand, Canada, Algeria, Zimbabwe, etc.) and beyond European maritime empires (the US, Israel, Russia, China and Japan). ${ }^{54}$ There is, then, no longer a need for a British world concept to place the history of British settle colonialism in a broader context.

Nor is it clear that that the British world concept is necessary to restore a consideration of the settlement empire to British imperial history. Duncan Bell has successfully revived an interest in the Victorian concept of 'Greater Britain' in the sphere of imperial thought, while earlier work by Andrew Thompson, along with publications by Simon Potter and Marc William Palen have all begun to re-emphasise the importance of the self-governing empire in British imperial thought without the 'world' or the attendant difficulties of Britishness. ${ }^{55}$ Of course 'Greater Britain' conceptually can only be used at a specific historical juncture in the late nineteenth and early twentieth centuries. The language of Greater Britain ultimately became sublimated into a language of Commonwealth against a backdrop of growing (and increasingly explicitly national) autonomy in the Dominions (as they became in 1907). ${ }^{56}$ John Darwin's resurrection of Alfred Zimmern's term 'the Third British Empire' is probably as good a solution as any to 
finding a term which encompasses the full chronological and special trajectories of the colonies of settlement. ${ }^{57}$ Alternatively one might, with $\mathrm{H}$. Duncan Hall, back-project the periodisation of the British Commonwealth of Nations from its conventional 1920s point of departure (an 'Empire-Commonwealth'?). ${ }^{58}$

The close analogy between the British world and the Empire-Commonwealth or Third British Empire becomes clear when examining the periodisation of the British world offered in much of the literature. Bridge and Fedorowich's suggested chronology illustrates the point: beginning with the loss of the American colonies in 1783, proceeding through the foundation of new (or reorganised) settler colonies down to the 1930s, before continuing to discuss patterns of migration, colonial autonomy and colonial identity, the Great War, the emergence of the British Commonwealth of Nations, the Second World War, the emergence of the new commonwealth, separate nationality, de-dominionisation and the legal repatriation of constitutions. ${ }^{59}$ This is, of course, in fact a history of the EmpireCommonwealth (a term even used in Bridge and Fedorowich's summary). Yet the punctuation of that history by wars and acts of state perhaps beg questions of neglect of the state in the conceptualisation of the British world. Often scholarship evades the problem by focusing on a cultural 'heyday' between the 1880 s and 1914 (or 1939) in a way that robs the British world of chronological specificity and in particular marginalises the technological, economic and geopolitical forces driving its formation, sustaining its existence, and ultimately eroding its coherence. ${ }^{60}$ Writing a history focusing on culture and networks yet implicitly periodised by global economics and geopolitics clearly presents fundamental conceptual problems. If this was globalisation from below, why is the periodization so obviously 'top down', framed by the chronology of British global politics? 
From this perspective, whether conceived as a sub-category of imperial history or as distinct from imperial history, the British world risks neglecting fundamental a concern of imperial history in all its varieties: power. On the one hand it neglects the power relations between settler societies and metropoles. Bridge and Fedorowich Bridge and Fedorowich argue that such debates are irrelevant, writing that "Collaboration is about "us" and "them", but the British world was emphatically about "we"'. ${ }^{61}$ Yet a shared British identity (shared by whom and why) by no means eliminates the possibility of unequal power dynamics. Financial, strategic, even cultural asymmetries are neglected within the British world in its eagerness to decentre and reject 'old' imperial history. ${ }^{62}$ James Belich's Replenishing the Earth restores ideas of economic asymmetry but does so by placing the economic dynamics of settler expansion rather than socio-cultural networks at the core of the analysis. ${ }^{63}$ On the other hand, the British world at times also risks neglecting settle colonialism and the internal and heavily unequal power dynamics between settlers and indigenous peoples (and the fact that such phenomenon were not limited to a British sphere). As Adele Perry has warned, 'deconstructing colonialism's self-serving success story is not without risks. In highlighting the local, the provisional, and the particular within colonialism, historians can find themselves, however inadvertently, downplaying the very real power of imperialism to reorder the map, the economy, the state(s), and, perhaps above all, to influence myriad social, political and intimate arrangements' ${ }^{64}$ Indigenous peoples often feature in British world collections only to note their exclusion from social networks or to highlight appeals to Britishness and the British monarchy.

Several British world authors are alive to the problem. Tamson Pietsch writes that, 'in accentuating the shared culture and identity of settler communities and their 
connections with Britain, the British World approach can be seen to have de-emphasized the uneven nature of power relations'. ${ }^{65}$ Magee and Thompson make the problem clear when they devote several sentences to the issue, writing:

as soon as we begin to re-imagine imperial geographies, we are faced with the tricky question of where power spatially resided. For the logic of a 'networked' or 'decentred' approach to studying empires is that metropole and settler colony acted and reacted upon each other in complex ways, and that sovereignty in the colonies, far from being static or stable, was subject to constant negotiation and renegotiation by a variety of settler and non-settler groups. ${ }^{66}$

Yet the problem is not simply that the British world approach neglects power. It is that network theory and a focus on identity in and of themselves (at least as currently formulated) struggle to tell us very much about power relations either on a macro-level, or on a micro-level.

Furthermore, given one of the primary aims throughout the British world project has been to move beyond some of the spatial boundaries of imperial and national histories, the actual history written under this label has largely stuck to a metropole-colony analysis. There is almost a complete absence of recognition that colonies had relationships with each other. There is much that could be gleaned about the real experiential power dynamics at play across these different spaces, as the work by Simon Potter and Rachel Bright has suggested. ${ }^{67}$ Instead the British world has largely simply duplicated the failures of imperial history to move beyond traditional spatial binaries. 
All of these issues are exacerbated because the British world concept usually sidesteps the categories of the political and constitutional. In so doing it fails to scrutinise explicitly the implications of late-nineteenth century imperial federalist ideas. ${ }^{68}$ For example, citing J. R. Seeley as evidence of the existence of a British world (a frequent device) is problematic on a number of levels. Seeley famously wrote:

We seem, as it were, to have conquered and peopled half the world in a fit of absence of mind. While we were doing it... we did not allow it to affect our imaginations or in any degree to change our way of thinking; nor have we even now ceased to think of ourselves as simply a race inhabiting an island off the northern coast of the Continent of Europe. ${ }^{69}$

The British world literature is in the habit of using Seeley to suggest a late Victorian consciousness of Greater Britain, not, as the passage makes clear, an absence and moreover an absence to be overcome though specific political projects undertaken by sections of elites across the empire. ${ }^{70}$ Seeley and his successors were not celebrating globalisation from below but pursuing integration and association from above.

The British world's acknowledged but underdeveloped debt to J. G. A. Pocock's conception of the new British history again points to the significance of a paradoxical failure to consider the political and the constitutional realms. Pocock conceived of British history as a quasi-organic entity - distinct and separated from European history - constituted through the integration of the varying ethnicities, but particularly polities of Britain and Ireland. Pocock's British history is political and constitutional; so too his extension of new British 
history overseas. Pocock's project, moreover, evolved as a reaction against the rupture of Britain's entry into Europe: it was one New Zealander's reaction to the political, economic, and constitutional changes in Anglo-dominion relations in the era of decolonization. ${ }^{71}$ Again, the British world concept seems framed by political and constitutional factors (and the monarchy features frequently in British world collections, along with flags, and other symbols of state identity) yet these factors (central to Pocock) are completely omitted from the British world's conceptual architecture. ${ }^{72}$ Greater Britain, the Third British Empire, Empire-Commonwealth, all these terms better serve to describe the unit of analysis dominating the British world literature. Thus, a more fruitful approach to addressing the concerns of the British world would have been to answer Francine McKenzie's call for a revived and enriched 'new Commonwealth History', perhaps (where appropriate) giving that history a transnational and post-colonial turn or engaging with the growing literature on settle colonialism. ${ }^{73}$

Is it possible to conceive of a British world more firmly separated from the British imperial or Commonwealth project? One alternative (not advocated here) might be to use the British world as foil to study global conceptions of race, harmonising with the central concern of post-colonial studies and the new imperial history. This would, naturally, encompass the study of the US and would constitute a dramatic departure from the concerns of the founders of the British world. Yet other, more appropriate, conceptual foils exist to perform this task. The rich field of Whiteness studies seeks to understand precisely the evolution and use of cultural, social and political power to make settler societies (including the US) 'white' spaces, and covers much of the same period. Lake and Reynolds' admirable overview highlights the global spread of ideas of 'whiteness' and legal 
frameworks set up to protect that 'whiteness'. ${ }^{74}$ It was a concept clearly globally separate from empire, and Britishness. Bill Schwarz's first volume of his trilogy on 'whiteness' within Britain and the settler empire deliberately chose the term 'white' over 'British', since this more accurately placed the focus on the identification central to his analysis. ${ }^{75}$ Our argument is not that this should not be an either/or British, British imperial, or white world. Rather it is that these are best held to be distinct but overlapping. Jonathan Hyslop, amongst others, has already examined some of the ways these identities could overlap and conflict; ${ }^{76}$ using the 'worlds' framework, in contrast, implies concrete boundaries which rarely existed in practice.

This leaves one final possibility for the 'British' world, interesting but more confined: the study of global or trans-national incarnations of British identity (or rather identities), In the exploration of the history of ideas of Britishness, its rise, flux, and fall lies the strongest case for having distinct British worlds analysis, rather than using frameworks like the British empire, Whiteness studies or settler colonialism. This project would not be limited to empire, but would be a chance to study how people constructed ideas of 'Britishness' to identify themselves and the worlds around them. The project might be executed by charting reconfigurations of ideas of Britain and Britishness along three vectors: Britishness as an identification; the global relations to Britain as a space; or networks and connections and boundaries and ruptures shaping such worlds. This conception is sufficiently distinct from the notion of a British imperium to ask searching questions about the relationship between incarnations of Britishness and empire's constitutional entity or power relations. Moreover, this approach must also include colonised peoples and opponents of empire, and not just as foils against which metropolitan and settler colonial Britishness was defined. It necessarily 
encompasses on an equal basis all claims by colonised peoples. The project should also encompass the constructions of Britain and Britishness across the rest of the world, for example in continental Europe, in the United States, or in the colonial empires of other European powers. The impact and interaction of these multiple strands would necessarily require the charting of these multiple constructions of Britishness, and a consideration of their impact on and acceptance or rejection by a plurality of groups. In short, this would be a Linda Colley-esque history of Britain and Britishness, but from a truly global perspective. However, as Tony Ballantyne has warned, if 'Britishness' is used as the analytical tool, it can also act as a throw-back to Dilke's celebration of empire, and gloss over the diverse identities of colonial societies. ${ }^{77}$ Only a global history of the multiple, patchy, and at times subversive uses to which vocabularies of Britishness have been put, by all actors within and beyond Britain and the British empire, is worth pursuing.

Such a study of global Britishness should not, however, be subsumed under the term British world, or even British worlds. To do so would obscure the very complex, conflicting, composite and often disconnected discourses at the heart of such a history. Indeed, the term British world must prove unhelpfully distorting because it implies uniform connection and singularity where in fact the focus of study is plural and often disconnected or connected in fitful and sporadic ways. It assumes the existence of a connected field - a world - where none may exist. To study Britishness globally is necessary to build from local and unique manifestations of self-declared Britishness, and then perhaps to proceed to establish specific connections or by way of comparisons, along with a consideration of the broader forces, the context, shaping these particular local manifestations of a global phenomenon. Because of this, we do not advocate using the term 'British world' to 
describe this project. Indeed, such the global study of Britishness is definitively not framed within a world, as it would be comparative in scope, not connected as worlds are meant to be. This is not an analysis of a British world but can only be one of often disconnected Britishness in the world.

III

Our purpose has not been not to deny the important intervention which the British world literature has made in the historiography of the British empire; we have both been helped and inspired by the work in this area to make global connections we would otherwise never have made. Rather our purpose has been to highlight that, in the end, this is the nature of the British world's achievement. It has brought disparate people together at conferences in a manner which many have found helpful. Historians have now rediscovered that an empire of settler capitalism and colonialism, increasingly self-governing and jealous of its autonomy, was a crucial component of Britain's empire. They have also returned the 'imperial factor' to the history of these and other regions. The British world also usefully emphasised the role of migration from the British Isles more broadly in the history of empire. ${ }^{78}$ Relations between Britain and the self-governing dominions cannot simply be understood through the prism of inter-governmental relations or economic dependence. In addition, the British world shed new light on other locations which were part of a broader imperial project, and sought to understand them in new ways, shifting away from older debates on informal empire.

These advances are not, however, best articulated through the distinct concept of the British world. Re-integrating the Dominions (as they became in 1907) and ultimately the 
'old Commonwealth' more fully into the historiography of empire clearly was necessary. It was not, however, necessary to develop a distinctive concept which rested solely on social networks and shared culture to do this. Other terms were and are available: Greater Britain, the 'third British empire' or even 'Empire-Commonwealth' all better capture a slippery constitutional and political history, the omission of which frequently led the British world approach to neglect of political culture and power. Combining this attention to ethnically British settler colonies (joined at times, with obvious reluctance, by the US) with the study of expatriate outposts within and beyond the empire, and the usages of languages of Britishness by other groups does not clarify our understanding of any of these phenomena.

Attempts to understand the British world as distinct from the British empire accentuate ambiguities which undermine the concept's utility. It is far from clear how that differentiation can be maintained or with what analytical gain. Consider for a moment the meaning of 'world', which emerged from the Atlantic world literature (which also sought differentiation from empire-driven histories). The Atlantic was an absolute space: an ocean. It was a relative space: connected by a certain conjunction of early modern maritime technologies. It was also a relational space: imagined and reimagined by those within its borders. A clear if fluid field of study emerges as a result. By contrast a British world divorced from empire can only be defined relationally, by Britishness. That creates conceptual problems, for Britishness itself is a mutable, fragile, and composite identity (like all identities). ${ }^{79}$

This critique of the British world has broader significance for the study of distinctive 'worlds' as a means of approaching the 'lumpy' nature of global history. It is clearly necessary for historians to appreciate as they take a global and transnational turn that not 
all areas are equally connected. Transnational connections vary in form and differ in density and intensity and consistency across space and time. ${ }^{80}$ Given this, there is perhaps a place for the usage of the term 'world' to denote a dense, intense, and consistent set of connections within the broader sweep of global history. However the case of the British world indicates how cautiously that term must be used. To construct a world around an identity alone when identity itself is such a slippery, mutable, and contingent concept can only lead to deep ambiguities. For a 'world' to have some purchase it cannot be defined purely endogenously by the mutable identities of its supposed members. To contribute to the burgeoning fields of transnational, and global, history, 'worlds' history must look without as well as within. 


\section{References}

Abu-Lughod, J. L., Before European hegemony: the world system a. D. 1250-1350 (New York, NY ; Oxford, 1989).

Alpers, E. A., The Indian Ocean in world history (Oxford 2014).

Anderson, B. M., 'The construction of an alpine landscape: building, representing and affecting the eastern Alps, c. 1885-1914', Journal of Cultural Geography, 29 (2012), pp. 155183.

Armitage, D., 'Greater Britain: A useful category of historical analysis?', American Historical Review, 104 (1999), pp. 427-445.

Armitage, D. and A. Bashford, eds., Pacific histories: ocean, land, people (Basingstoke, 2014).

Armitage, D. and M. J. Braddick, eds., The British Atlantic world, 1500-1800 (Basingstoke, 2002).

Attard, B., 'From free-trade imperialism to structural power: New Zealand and the capital market, 1856-68', Journal of Imperial and Commonwealth History, 35 (2007), pp. 505 - 527. Attard, B. and A. R. Dilley, 'Finance, empire and the British world', a special issue of Journal of Imperial and Commonwealth History, 41 (2013).

Ballantyne, T., Orientalism and race: Aryanism in the British empire (Basingstoke, 2001).

Ballantyne, T., 'Race and the webs of empire', Journal of Colonialism and Colonial History, 2 (2001).

Ballantyne, T., 'Colonial knowledge', in S.E. Stockwell, ed., The British empire: themes and perspectives (Oxford, 2008), pp. 177-198. 
Bateman, F. and L. Pilkington, Studies in settle colonialism: politics, identity and culture (Basingstoke, 2011).

Bayly, C. A., The birth of the modern world, 1780-1914: global connections and comparisons (Oxford, 2004).

Belich, J., 'The rise of the Angloworld: settlement in North America and Australasia, 17841918', in P.A. Buckner and R.D. Francis, eds., Rediscovering the British world (Calgary, 2005), pp. 39-58.

Belich, J., Replenishing the earth: the settler revolution and the rise of the anglo-world, 17831939 (Oxford, 2009).

Bell, D., The idea of Greater Britain: empire and the future of world order, 1860-1900 (Princeton, NJ, 2007).

Bennison, A. K., 'Muslim universalism and western globalization', in A.G. Hopkins, ed., Globalization in world history (London, 2002), pp. 74-97.

Bickers, R., 'Shanghailanders: the formation and identity of the British settler community in Shanghai 1843-1937', Past \& Present, 159 (1998), pp. 161-211.

Bickers, R. A., Britain in China: community, culture and colonialism, 1900-49 (Manchester, 1999).

Boehmer, E., 'Where we belong: South Africa as a settler colony and the calibration of African and Afrikaner indigeneity', in F. Bateman and L. Pilkington, eds., Studies in settle colonialism: politics, identity and culture (Basingstoke, 2011), pp. 257-271.

Bourke, R., 'Pocock and the presuppositions of the new British history', Historical Journal, 53 (2010), pp. 747-770. 
Bridge, C. and K. Fedorowich, eds., The British world: diaspora, culture, and identity (London, 2003).

Bridge, C. and K. Fedorowich, 'Mapping the British world', in C. Bridge and K. Fedorowich, eds., The British world: diaspora, culture, and identity (London, 2003), pp. 1-15.

Briggs, L., G. McCormick and J. T. Way, 'Transnationalism: a category of analysis', American Quarterly, 60 (2008), pp. 625-648.

Bright, R., 'Asian migration and the British world, 1850-1914', in K. Fedorowich and A. Thompson, eds., Empire, identity and migration in the British world (Manchester, 2013).

Bright, R., Chinese labour in South Africa, 1902-10: race, violence, and global spectacle (Basingstoke, 2013).

Buckner, P., 'Whatever happened to the British empire', Journal of the Canadian Historical Association, 4 (1993), pp. 3-32.

Buckner, P., 'Introduction', in P. Buckner, ed., Canada and the British empire (Oxford, 2008), pp. 1-22.

Buckner, P. and C. Bridge, 'Re-inventing the British world', The Round Table, 92 (2003), pp. 77-88.

Buckner, P. A., 'Was there a "British" empire? The Oxford history of the British empire from a Canadian perspective.', Acadiensis, 32 (2002), pp. 110-28.

Buckner, P. A. and R. D. Francis, eds., Rediscovering the British world (Calgary, 2005).

Buckner, P. A. and R. D. Francis, eds., Canada and the British world: Culture, migration, and identity (Vancouver, 2006).

Burton, A., 'Who needs the nation? Interrogating 'British' history', Journal of Historical Sociology, 10 (1997), pp. 227-248. 
Cain, P. J. and A. G. Hopkins, 'Afterword: the theory and practice of British imperialism', in R.E. Dumett, ed., Gentlemanly capitalism and British imperialism: The new debate on empire (London, 1999), pp. 196-220.

Cain, P. J. and A. G. Hopkins, British imperialism, 1688-2000 (Harlow, 2001).

Chambers, D. B., 'The black Atlantic: theory, method, and practice', in T. Falola and K.D. Roberts, eds., The Atlantic world: 1450-2000 (Bloomington, IND, 2008), pp. 151-174.

Chilton, L., 'Canada and the British empire: A review essay', Canadian Historical Review, 89 (2008), pp. 89-95.

Clarke, P., 'The English-speaking peoples before Churchill', Britain and the World, 4 (2011), pp. 199-231.

Clavin, P., 'Defining transnationalism', Contemporary European History, 14 (2005), pp. 421439.

Colley, L., 'Britishness and otherness: an argument', Journal of British Studies, 31 (1992), pp. 309-329.

Colley, L., Britons: forging the nation, 1707-1837 (London, 1992).

Constantine, S., 'British emigration to the empire-commonwealth since 1880: From overseas settlement to diaspora?', in C. Bridge and K. Fedorowich, eds., The British world: Diaspora, culture, and identity (London, 2003), pp. 16-35.

Cooper, F., 'What is the concept of globalization good for? An african historian's perspective', African Affairs, 100 (2001), pp. 189-213.

Cooper, F. and R. Brubaker, 'Identity', in F. Cooper, ed., Colonialism in question: theory, knowledge, history (Berkeley, CA, 2005), pp. 59-90. 
Darian-Smith, K., P. Grimshaw and S. Macintyre, Britishness abroad: transnational movements and imperial cultures (Carlton, Vic., 2007).

Darwin, J., 'A third British empire? The dominion idea in imperial politics', in J.M. Brown and W.R. Louis, eds., Oxford history of the British empire: vol 4: The twentieth century (Oxford, 1999), pp. 64-87.

Davidson, J., 'The de-dominionisation of Australia', Meanjin, 32 (1979), pp. 139-151.

Denoon, D., Settler capitalism: The dynamics of dependent development in the southern hemisphere (Oxford, 1983).

Dilke, C. W., Greater Britain: A record of travel in English-speaking countries during 1866 and 1867 (London, 1868).

Dilke, C. W., Problems of greater Britain (London, 1890).

Dilley, A., 'Empire, globalisation, and the cultural economy of the British world', Journal for Maritime Research, 14 (2012).

Dilley, A., Finance, politics, and imperialism: Australia, Canada, and the city of London, c.1896-1914 (Basingstoke, 2012).

Dubow, S., 'How British was the British world? The case of South Africa', Journal of Imperial and Commonwealth History, 37 (2009), pp. 1-27.

Dumett, R. E., e.d., Gentlemanly capitalism and British imperialism: The new debate on empire (London, 1999).

Edmonds, P. and J. Carey, 'A new beginning for settler colonial studies', Settler Colonial Studies, 3 (2013), pp. 2-5.

Eley, G., 'Historicizing the global, politicizing capital: giving the present a name', History Workshop Journal, 63 (2007), pp. 154-188. 
Elkins, C. and S. Pedersen, 'Introduction - settle colonialism: a concept and its uses', in C. Elkins and S. Pedersen, eds., Settle colonialism in the twentieth century: projects, practices, legacies (New York, NY; London, 2005), pp. 1-20.

Elkins, C. and S. Pedersen, Settle colonialism in the twentieth century: projects, practices, legacies (New York, NY; London, 2005).

Falola, T. and K. D. Roberts, eds., The Atlantic world: 1450-2000 (Bloomington, IND, 2008).

Flynn, D. O., L. Frost and A. J. H. Latham, eds., Pacific centuries: Pacific and Pacific rim economic history since the 16th century (London, 1999).

Gilroy, P., The black Atlantic: Modernity and double consciousness (Cambridge, Mass., 1993).

Greene, J. P. and P. D. Morgan, eds., Atlantic history: A critical appraisal (Oxford, 2009).

Hall, C., 'What did a British world mean to the British', in P.A. Buckner and R.D. Francis, eds., Rediscovering the British world (Calgary, 2005), pp. 21-38.

Hall, H. D., The British Commonwealth of Nations (London, 1920).

Hall, H. D., Commonwealth (London, 1971).

Harper, M. and S. Constantine, Migration and empire (Oxford, 2010).

Harvey, D., 'Space as a keyword', in D. Harvey, ed., Spaces of global capitalism (London, 2006), pp. 119-48.

Harvey, D., Cosmopolitanism and the geographies of freedom (New York, NY; Chichester, 2009).

Hopkins, A. G., 'Informal empire in Argentina: an alternative view', Journal of Latin American Studies, 26 (1994), pp. 469-484.

Hopkins, A. G., 'Back to the future: from national history to imperial history', Past and Present, 164 (1999), pp. 198-243. 
Hopkins, A. G., ed., Globalization in world history (London, 2002).

Hopkins, A. G., 'Gentlemanly capitalism in New Zealand', Australian Economic History Review, 43 (2003), pp. 287-297.

Hopkins, A. G., ed., Global history: interactions between the universal and the local (Basingstoke, 2006).

Hopkins, A. G., 'Rethinking decolonization', Past \& Present, 200 (2008), pp. 211-247.

Howe, S., 'British worlds, settler worlds, world systems, and killing fields', Journal of Imperial and Commonwealth History, 40 (2012), pp. 691-725.

Hyslop, J., 'The imperial working class makes itself 'white': white labourism in Britain, australia, and south africa before the first world war', Journal of Historical Sociology, 12 (1999), pp. 398-421.

Hyslop, J., "The British and australian leaders of the south african labour movement, 19021914: a group biography", in K. Darian-Smith, P. Grimshaw and S. Macintyre, eds., Britishness abroad: transnational movements and imperial cultures (Carlton, Vic., 2007), pp. 90-108.

Kennedy, D., 'Imperial history and post-colonial theory', Journal of Imperial and Commonwealth History, 24 (1996).

Laidlaw, Z., Colonial connections, 1815-45: patronage, the information revolution and colonial government (Manchester, 2005).

Lake, M. and H. Reynolds, Drawing the global colour line: white men's countries and the international challenge of racial equality (Cambridge, 2008).

Lester, A., Imperial networks: creating identities in nineteenth century south africa and Britain (London, 2001). 
Lester, A., 'Imperial circuits and networks: geographies of the British empire', History Compass, 4 (2006), pp. 124-141.

Lloyd, C., J. Metzer and R. Sutch, Settler economies in world history (Leiden, 2013).

Louis, W. R., ed., Imperialism: the Robinson and Gallagher controversy (New York, 1976).

MacKenzie, J. M., 'Irish, Scottish, Welsh, and English worlds? The historiography of a fournations approach to the British empire', in C. Hall and K. McClelland, eds., Race, nation and empire: making histories, 1750 to the present (Manchester, 2010), pp. 133-153.

Magee, G. and A. Thompson, 'Author's response to Dr Stuart Ward, review of Empire and globalisation: networks of people, goods and capital in the British world, c.1850-1914', Reviews in History, 1000 (2010).

Magee, G. and A. Thompson, Empire and globalisation: networks of people, goods and capital in the British world, c.1850-1914 (Cambridge, 2010).

McIntyre, W. D., The britannic vision: historians and the making of the British Commonwealth of Nations, 1907-48 (Basingstoke, 2009).

McKenzie, F., Redefining the bonds of Commonwealth, 1939-1948: the politics of preference (Basingstoke, 2002).

O'Brien, P., 'Historiographical traditions and modern imperatives for the restoration of global history', Journal of Global History, 1 (2006), pp. 3-39.

O'Rourke, K. H. and J. G. Williamson, Globalization and history: the evolution of a nineteenthcentury Atlantic economy (Cambridge, MA; London, 1999).

Palen, M.-W., 'Adam Smith as advocate of empire, c.1870-1932', Historical Journal, 57, pp. 179-198. 
Pearson, M. N., The world of the Indian ocean, 1500-1800: studies in economic, social and cultural history (Aldershot, 2005).

Perry, A., "Whose world was British? Rethinking the "British world" from an edge of empire", in K. Darian-Smith, P. Grimshaw and S. Macintyre, eds., Britishness abroad: transnational movements and imperial cultures (Carlton, Vic., 2007).

Pickles, K., ' The obvious and the awkward: post-colonialism and the British world', New Zealand Journal of History, 45 (2011), pp. 85-101.

Pietsch, T., Empire of scholars: universities, networks and the British academic world, 18501939 (Manchester, 2013).

Pietsch, T., 'Rethinking the British world', Journal of British Studies, 52 (2013), pp. 441-463.

Platt, D. C. M. and G. Di Tella, eds., Argentina, Australia and Canada: studies in comparative development 1870-1965 (London, 1985).

Pocock, J. G. A., 'The new British history in Atlantic perspective: an antipodean commentary', American Historical Review, 104 (1999), pp. 490-500.

Pocock, J. G. A., The discovery of islands: essays in British history (Cambridge, 2005).

Potter, S. J., News and the British world: the emergence of an imperial press system, 18761922 (Oxford, 2003).

Potter, S. J., 'Richard Jebb, John S. Ewart and the Round Table, 1898-1926', English Historical Review, CXXII (2007), pp. 105-132.

Potter, S. J., 'Webs, networks and systems: globalization and the mass media in the nineteenth- and twentieth-century British empire', Journal of British Studies, 46 (2007), pp. 621-646.

Potter, S. J., Broadcasting empire: the BBC and the British world, 1922-1970 (Oxford, 2012). 
Proudfoot, L. and D. Hall, Imperial spaces: placing the Irish and the Scots in colonial Australia (Manchester, 2011).

Schreuder, D. and S. Ward, 'Introduction: what became of Australia's empire?', in D. Schreuder and S. Ward, eds., Australia's empire (Oxford, 2008), pp. 1-25.

Schwarz, B., Memories of empire: Vol 1: The white man's world (Oxford, 2011).

Seeley, J. R., The expansion of England (London, 1883).

Sheppard, E., 'David Harvey and dialectical space-time', in N. Castree and D. Gregory, eds., David harvey : A critical reader (Oxford, 2006).

Sivasundaram, S. a., Islanded : Britain, Sri Lanka, and the bounds of an indian ocean colony (Chicago, IL, 2013).

Smith, A., 'Patriotism, self-interest and the 'empire effect': Britishness and British decisions to invest in Canada, 1867-1914', The Journal of Imperial and Commonwealth History, 41 (2013), pp. 59-80.

Thompson, A., 'The languages of loyalism in southern Africa, c. 1870-1939', English Historical Review, 118 (2003), pp. 617-650.

Veracini, L., 'Introducing', Settler Colonial Studies, 1 (2011), pp. 1-12.

Veracini, L., "'Settle colonialism"': career of a concept', Journal of Imperial and Commonwealth History, 41 (2013), pp. 313-333.

Weaver, J. A., The red atlantic: American indigenes and the making of the modern world, 1000-1927(

Wilson, K., A new imperial history: culture, identity, and modernity in Britain and the empire, 1660-1840 (Cambridge, 2004).

Zimmern, A., The third British empire (London, 1926). 
Contact Details: Dr Rachel Bright,

History

School of Humanities

Keele University

Keele

Staffordshire

ST5 5BG

r.k.bright@keele.ac.uk

Dr Andrew Dilley

Department of History

University of Aberdeen

Crombie Annex

Meston Walk

Old Aberdeen

Scotland

AB24 3FX

${ }^{1}$ For challenges to the nation state and transnational history, A. Burton, 'Who needs the nation? Interrogating "British" history', Journal of Historical Sociology, 10 (1997), pp. 227248; A.G. Hopkins, 'Back to the future: from national history to imperial history', Past and Present, 164 (1999), pp. 198-243; P. Clavin, 'Defining transnationalism', Contemporary 
European History, 14 (2005), pp. 421-439; L. Briggs, G. McCormick and J.T. Way, 'Transnationalism: a category of analysis', American Quarterly, 60 (2008), pp. 625-648. For global history, see C.A. Bayly, The birth of the modern world, 1780-1914: global connections and comparisons (Oxford, 2004); P. O'Brien, 'Historiographical traditions and modern imperatives for the restoration of global history', Journal of Global History, 1 (2006), pp. 339; A.G. Hopkins, ed., Globalization in world history (London, 2002); idem, ed., Global history: interactions between the universal and the local (Basingstoke, 2006); G. Eley, 'Historicizing the global, politicizing capital: giving the present a name ', History Workshop Journal, 63 (2007), pp. 154-188.

${ }^{2}$ B. Bailyn, 'Preface', in D. Armitage and M. J. Braddick, eds., The British Atlantic World, 1500-1800 (Basingstoke, 2002), p. xix.

${ }^{3}$ On the Atlantic world, see D. Armitage and M.J. Braddick, eds., The British atlantic world, 1500-1800 (Basingstoke, 2002); J.P. Greene and P.D. Morgan, eds., Atlantic history: a critical appraisal (Oxford, 2009). On the Indian Ocean, see M.N. Pearson, The world of the Indian ocean, 1500-1800: studies in economic, social and cultural history (Aldershot, 2005); E.A. Alpers, The Indian ocean in world history (Oxford 2014); S.A. Sivasundaram, Islanded: Britain, Sri Lanka, and the bounds of an Indian ocean colony (Chicago, IL, 2013). On the Pacific, see D.O. Flynn, L. Frost and A.J.H. Latham, eds., Pacific centuries: Pacific and Pacific rim economic history since the 16th century (London, 1999); D. Armitage and A. Bashford, eds., Pacific histories: ocean, land, people (Basingstoke, 2014).

${ }^{4}$ For critiques of Atlantic history, see Chaplin and Coclanis in Greene and Morgan, eds., Atlantic history. 
${ }^{5}$ J.L. Abu-Lughod, Before european hegemony: The world system a. D. 1250-1350 (New York ; Oxford, 1989); A.K. Bennison, 'Muslim universalism and western globalization', in A.G. Hopkins, ed., Globalization in world history (London, 2002).

${ }^{6}$ Greene and Morgan, eds., Atlantic history; T. Falola and K.D. Roberts, eds., The Atlantic world: 1450-2000 (Bloomington, Ind., 2008); J.a. Weaver, The red Atlantic: American indigenes and the making of the modern world, 1000-1927. Paul Gilroy's influential The black Atlantic: modernity and double consciousness (Cambridge, Mass., 1993) has a complex relationship with Atlantic History. See D.B. Chambers, 'The black Atlantic: theory, method, and practice', in T. Falola and K.D. Roberts, eds., The Atlantic world: 1450-2000 (Bloomington, Ind., 2008).

${ }^{7}$ Key works are cited throughout.

${ }^{8}$ P.A. Buckner and R.D. Francis, 'Introduction', in P.A. Buckner and R.D. Francis, eds., Rediscovering the British world (Calgary, 2005), p. 17. See also P. Buckner and C. Bridge, 'Reinventing the British world', The Round Table, 92 (2003), pp. 77-88.

${ }^{9}$ P.A. Buckner, 'Was there a "British" empire? The Oxford history of the British empire from a Canadian perspective.', Acadiensis, 32 (2002), pp. 110-28.

${ }^{10}$ For example, W.R. Louis, ed., Imperialism: the Robinson and Gallagher controversy (New York, 1976). However, the dominions became important in the gentlemanly capitalism debate. See essays by Kubicek, Davis, and Cain and Hopkins in R.E. Dumett, e.d., Gentlemanly capitalism and British imperialism: the new debate on empire (London, 1999).

${ }^{11}$ D. Kennedy, 'Imperial history and post-colonial theory', Journal of Imperial and Commonwealth History, 24 (1996); T. Ballantyne, 'Colonial knowledge', in S.E. Stockwell, ed., The British empire: themes and perspectives (Oxford, 2008); K. Wilson, A new imperial 
history: culture, identity, and modernity in Britain and the empire, 1660-1840 (Cambridge, 2004).

${ }^{12}$ Hopkins, 'Back to the future', pp. 216-8. P. Buckner, 'Whatever happened to the British empire', Journal of the Canadian Historical Association, 4 (1993), pp. 3-32.

${ }^{13}$ D. Denoon, Settler capitalism: The dynamics of dependent development in the southern hemisphere (Oxford, 1983); D.C.M. Platt and G. Di Tella, eds., Argentina, Australia and Canada: studies in comparative development 1870-1965 (London, 1985).

${ }^{14}$ D. Schreuder and S. Ward, 'Introduction: What became of Australia's empire?', in D. idem., eds., Australia's empire (Oxford, 2008), p. 11. See also P. Buckner, 'Introduction', in idem. ed., Canada and the British empire (Oxford, 2008), pp. 12-13.

${ }^{15}$ Buckner and Bridge, 'Re-inventing the British world'; Buckner and Francis, 'Introduction', p. 7.

${ }^{16} \mathrm{C}$. Bridge and K. Fedorowich, 'Mapping the British world', in idem., eds., The British world: Diaspora, culture, and identity (London, 2003), p. 1

${ }^{17}$ J.G.A. Pocock, 'The new British history in Atlantic perspective: An antipodean commentary', American Historical Review, 104 (1999), pp. 490-500 at p. 500.

${ }^{18}$ Quoted in Buckner and Bridge, 'Re-inventing the British world', p. 81.

${ }^{19}$ Bridge and Fedorowich, 'The British world', p. 6.

${ }^{20}$ Diaspora is frequently used in the British world literature as a synonym for migration. Stephen Constantine has offered a thoughtful justification. See S. Constantine, 'British emigration to the empire-commonwealth since 1880: From overseas settlement to diaspora?' in Bridge and Fedorwich, The British world. See also Dr Esme Cleall, 'Review of 
Empire, migration and identity in the British world', Reviews in History, 1597 (2016), DOI: 10.14296/RiH/2014/1597.

${ }^{21}$ Buckner and Francis, 'Introduction', p. 18.

${ }^{22}$ L. Colley, Britons: Forging the nation, 1707-1837 (London, 1992); idem., 'Britishness and otherness: an argument', Journal of British Studies, 31 (1992), pp. 309-329. On a 'four nations' approach to British imperial history, see J.M. MacKenzie, 'Irish, Scottish, Welsh, and English worlds? The historiography of a four-nations approach to the British empire', in C. Hall and K. McClelland, eds., Race, nation and empire: making histories, 1750 to the present (Manchester, 2010). On Irish and Scottish ethnicity in Australia, see L. Proudfoot and D. Hall, Imperial spaces: placing the Irish and the Scots in colonial Australia (Manchester, 2011). British world conference organisers also sought out keynote papers from leading figures in the new imperial history, which built on postcolonial influences to place new British history in global context. Nonetheless an uneasy relationship has existed the relationship between new Imperial history and with its post-colonial emphasis on the construction of difference, and the British world's with its soft focus on sameness. Only Hall has published under the British world banner, but to closely equate the British world with British imperium. See C. Hall, 'What did a British world mean to the British', in Buckner and Francis, eds., Rediscovering the British world. See also K. Pickles, 'The obvious and the awkward: postcolonialism and the British world', New Zealand Journal of History, 45 (2011), pp. 85-101. ${ }^{23}$ A. Lester, Imperial networks: creating identities in nineteenth century South Africa and Britain (London, 2001); A. Lester, 'Imperial circuits and networks: geographies of the British empire', History Compass, 4 (2006), pp. 124-141; Z. Laidlaw, Colonial connections, 1815-45: patronage, the information revolution and colonial government (Manchester, 2005); T. 
Ballantyne, 'Race and the webs of empire', Journal of Colonialism and Colonial History, 2 (2001). See also, S.J. Potter, 'Webs, networks and systems: globalization and the mass media in the nineteenth- and twentieth-century British empire', Journal of British Studies, 46 (2007), pp. 621-646.

${ }^{24}$ D. Armitage, 'Greater Britain: a useful category of historical analysis?', American Historical Review, 104 (1999), pp. 427-445; Armitage and Braddick, eds., British Atlantic world. ${ }^{25}$ Bridge and Fedorowich, eds., The British world; P.A. Buckner and R.D. Francis, eds., Canada and the British world: Culture, migration, and identity (Vancouver, 2006); Buckner and Francis, eds., Rediscovering the British world; K. Darian-Smith, P. Grimshaw and S. Macintyre, Britishness abroad: Transnational movements and imperial cultures (Carlton, Vic., 2007).

${ }^{26}$ Buckner and Bridge, 'Re-inventing the British world', p. 87.

${ }^{27}$ Buckner and Francis, eds., Rediscovering the British world.

${ }^{28}$ R. Bickers, 'Shanghailanders: The formation and identity of the British settler community in Shanghai 1843-1937', Past \& Present, 159 (1998), pp. 161-211.

${ }^{29}$ For a succinct discussion, see W.D. McIntyre, The britannic vision: historians and the making of the British Commonwealth of Nations, 1907-48 (Basingstoke, 2009), pp. 76-80. ${ }^{30}$ See R.A. Bickers, Britain in China: community, culture and colonialism, 1900-49 (Manchester, 1999); Bickers, 'Shanghailanders'; P.J. Cain and A.G. Hopkins, British imperialism, 1688-2000 (Harlow, 2001), pp. 274, 530.

${ }^{31}$ There has also been a rich crop of more focused research monographs under the banner of the British world. Almost all are explicitly conceived as contributions to British imperial history focusing on the settler colonies and use the term British world as a convenient 
synonym for the dominions. See for example, S.J. Potter, News and the British world: The emergence of an imperial press system, 1876-1922 (Oxford, 2003); idem., Broadcasting empire: the BBC and the British world, 1922-1970 (Oxford, 2012); T. Pietsch, Empire of scholars: universities, networks and the British academic world, 1850-1939 (Manchester, 2013). The same is also true of B. Attard and A. R. Dilley, 'Finance, empire and the British world', a special issue of Journal of Imperial and Commonwealth History, 41 (2013).

${ }^{32} \mathrm{G}$. Magee and A. Thompson, Empire and globalisation: Networks of people, goods and capital in the British world, c.1850-1914 (Cambridge, 2010). For further discussion, see A. Dilley, 'Empire, globalisation, and the cultural economy of the British world', Journal for Maritime Research, 14 (2012); S. Howe, 'British worlds, settler worlds, world systems, and killing fields', Journal of Imperial and Commonwealth History, 40 (2012), pp. 691-725.

${ }^{33}$ Magee and Thompson, Empire and globalisation, p. 231.

${ }^{34}$ G. Magee and A. Thompson, 'Author's response to Dr Stuart Ward, "review of empire and globalisation: Networks of people, goods and capital in the British world, c.1850-1914"', Reviews in History, 1000 (2010).

${ }^{35}$ C.W. Dilke, Greater Britain: a record of travel in English-speaking countries during 1866 and 1867 (London, 1868); idem, Problems of greater Britain (London, 1890).

${ }^{36}$ D. Bell, The idea of greater Britain: empire and the future of world order, $1860-1900$ (Princeton, N.J., 2007).

${ }^{37}$ A. Smith, 'Patriotism, self-interest and the 'empire effect': Britishness and British decisions to invest in Canada, 1867-1914', The Journal of Imperial and Commonwealth History, 41 (2013), pp. 59-80; P. Clarke, 'The English-speaking peoples before Churchill', Britain and the World, 4 (2011), pp. 199-231. 
${ }^{38}$ K.H. O'Rourke and J.G. Williamson, Globalization and history: the evolution of a nineteenth-century Atlantic economy (Cambridge, MA; London, 1999).

${ }^{39}$ Belich, Replenishing the earth.

${ }^{40}$ Potter, News and the British world; idem, Broadcasting empire.

${ }^{41}$ T. Pietsch, 'Rethinking the British world', Journal of British Studies, 52 (2013), pp. 441-463 at p. 447.

${ }^{42}$ Ibid., 449 citing D. Harvey, 'Space as a keyword', in idem., ed., Spaces of global capitalism (London, 2006), p. 125; idem., Cosmopolitanism and the geographies of freedom (New York, NY; Chichester, 2009), p. 135; E. Sheppard, 'David Harvey and dialectical space-time', in N.

Castree and D. Gregory, eds., David Harvey: a critical reader (Oxford, 2006).

${ }^{43}$ Pietsch, 'Rethinking the British world', p. 456.

${ }^{44}$ B.M. Anderson, 'The construction of an alpine landscape: building, representing and affecting the eastern Alps, c. 1885-1914', Journal of Cultural Geography, 29 (2012), pp. 155183.

${ }^{45}$ S. Dubow, 'How British was the British world? The case of South Africa', Journal of Imperial and Commonwealth History, 37 (2009), pp. 1-27 at pp. 6-7.

${ }^{46}$ Lowry quoted in ibid., 17.

${ }^{47}$ Ibid., 19

${ }^{48}$ A. Thompson, 'The languages of loyalism in southern Africa, c. 1870-1939', English Historical Review, 118 (2003), pp. 617-650 at pp. 620, 622, 647.

49 J. Belich, Replenishing the earth: the settler revolution and the rise of the anglo-world, 1783-1939 (Oxford, 2009).

${ }^{50}$ C. Lloyd, J. Metzer and R. Sutch, Settler economies in world history (Leiden, 2013). 
${ }^{51}$ L. Veracini, 'Introducing', Settler Colonial Studies, 1 (2011), pp. 1-12 at p. 2; idem, 'Settler colonialism': Career of a concept', Journal of Imperial and Commonwealth History, 41 (2013), pp. 313-333; C. Elkins and S. Pedersen, 'Introduction - settler colonialism: a concept and its uses', in idem., eds., Settler colonialism in the twentieth century: projects, practices, legacies (New York, NY; London, 2005); P. Edmonds and J. Carey, 'A new beginning for settler colonial studies', Settler Colonial Studies, 3 (2013), pp. 2-5.

${ }^{52}$ A good example is E. Boehmer 'Where we belong: South Africa as a settler colony and the calibration of African and Afrikaner indigeneity', in F. Bateman and L. Pilkington, eds., Studies in settler colonialism: politics, identity and culture (Basingstoke, 2011).

${ }^{53}$ The first issue of the Settler Colonial Studies journal, in 2011, was subtitled 'A global phenomenon'.

${ }^{54}$ See Elkins and Pedersen, Settler colonialism in the twentieth; Bateman and Pilkington, Studies in settler colonialism.

${ }^{55}$ Bell, Idea of greater Britain; Potter, 'Webs, networks and systems'; idem, 'Richard Jebb, John S. Ewart and the Round Table, 1898-1926', English Historical Review, CXXII (2007), pp. 105-132; M.-W. Palen, 'Adam smith as advocate of empire, c.1870-1932', Historical Journal, 57, pp. $179-198$.

${ }^{56}$ Mclntyre, Britannic vision; Bell, Idea of greater Britain.

${ }^{57}$ J. Darwin, 'A third British empire? The dominion idea in imperial politics', in J.M. Brown and W.R. Louis, eds., Oxford history of the British empire: vol 4: The twentieth century (Oxford, 1999); A. Zimmern, The third British empire (London, 1926).

${ }^{58}$ H.D. Hall, The British Commonwealth of Nations (London, 1920); H.D. Hall, Commonwealth (London, 1971). 
${ }^{59}$ Bridge and Fedorowich, 'The British world', pp. 9-11.

${ }^{60}$ Simon Potter's on the media is an important exception, but sits squarely within imperial history. See Potter, News and the British world; idem, Broadcasting empire. A. G. Hopkins's significant re-integration of the old dominions into the history of decolonisation highlights the role of global economic, political, and cultural forces in eroding the Anglo-dominion connection. See A.G. Hopkins, 'Rethinking decolonization', Past \& Present, 200 (2008), pp. 211-247.

${ }^{61}$ Bridge and Fedorowich, 'The British world', p. 4.

${ }^{62}$ The debate surrounding the later work of Cain and Hopkins on 'structural power' remains a more useful point of departure. See P.J. Cain and A.G. Hopkins, 'Afterword: The theory and practice of British imperialism', in R.E. Dumett, ed., Gentlemanly capitalism and British imperialism: The new debate on empire (London, 1999); A.G. Hopkins, 'Informal empire in Argentina: An alternative view', Journal of Latin American Studies, 26 (1994), pp. 469-484; idem., 'Gentlemanly capitalism in New Zealand', Australian Economic History Review, 43 (2003), pp. 287-297; B. Attard, 'From free-trade imperialism to structural power: New Zealand and the capital market, 1856-68', Journal of Imperial and Commonwealth History, 35 (2007), pp. 505 - 527; A. Dilley, Finance, politics, and imperialism: Australia, Canada, and the city of London, c.1896-1914 (Basingstoke, 2012).

${ }^{63}$ Belich, Replenishing the earth.

${ }^{64}$ A. Perry, "Whose world was British? Rethinking the "British world" from an edge of empire", in K. Darian-Smith, P. Grimshaw and S. Macintyre, eds., Britishness abroad: transnational movements and imperial cultures (Carlton, Vic., 2007), pp. 134-5.

${ }^{65}$ Pietsch, 'Rethinking the British world', p. 446; Dubow, 'How British', p. 2. 
${ }^{66}$ Magee and Thompson, Empire and globalisation, pp. 25-26.

${ }^{67}$ Potter, News and the British world; R. Bright, Chinese labour in South Africa, 1902-10: race, violence, and global spectacle (Basingstoke, 2013).

${ }^{68}$ For one critic alive to the seeming revival of a celebratory imperial history, see L. Chilton, 'Canada and the British empire: a review essay', Canadian Historical Review, 89 (2008), pp. 89-95.

${ }^{69}$ J.R. Seeley, The expansion of England (London, 1883), p. 11.

${ }^{70}$ Potter, 'Richard Jebb'.

${ }^{71}$ On these changes, see Hopkins, 'Rethinking decolonization'; J. Davidson, 'The dedominionisation of Australia', Meanjin, 32 (1979), pp. 139-151.

72 J.G.A. Pocock, The discovery of islands: essays in British history (Cambridge, 2005); R. Bourke, 'Pocock and the presuppositions of the new British history', Historical Journal, 53 (2010), pp. 747-770.

${ }^{73} \mathrm{~F}$. McKenzie, Redefining the bonds of Commonwealth, 1939-1948: the politics of preference (Basingstoke, 2002), pp. 266-268.

${ }^{74} \mathrm{M}$. Lake and H. Reynolds, Drawing the global colour line: white men's countries and the international challenge of racial equality (Cambridge, 2008). See also R. Bright, 'Asian migration and the British world, 1850-1914', in K. Fedorowich and A. Thompson, eds., Empire, identity and migration in the British world (Manchester, 2013); J. Hyslop, 'The imperial working class makes itself 'white': white labourism in Britain, Australia, and South Africa before the First World War', Journal of Historical Sociology, 12 (1999), pp. 398-421. ${ }^{75}$ B. Schwarz, Memories of empire: Vol 1: the white man's world (Oxford, 2011), p. 15. 
${ }^{76}$ Hyslop, 'Imperial working class'; idem, "The British and Australian leaders of the South African labour movement, 1902-1914: A group biography", in Darian-Smith, Grimshaw and Macintyre, eds., Britishness abroad.

${ }^{77}$ T. Ballantyne, Orientalism and race: Aryanism in the British empire (Basingstoke, 2001), p. 3.

${ }^{78}$ M. Harper and S. Constantine, Migration and empire (Oxford, 2010).

${ }^{79}$ Frederick Cooper and Rogers Brubaker offer an excellent critique of the imprecisions of the concept of identity. See F. Cooper and R. Brubaker, 'Identity', in F. Cooper, ed., Colonialism in question: theory, knowledge, history (Berkeley, CA, 2005).

${ }^{80}$ Idem., 'What is the concept of globalization good for? An African historian's perspective', African Affairs, 100 (2001), pp. 189-213. 